\title{
Khasiat Jamu Antidiabetes pada Tikus Sprague Dawley yang Diinduksi Streptozocin
}

\author{
(Efficacy of Antidiabetic Jamu in Streptozotocin-Induced Diabetic Rats)
}

\author{
Penulis \\ Ning Harmanto ${ }^{1}$, Innes Maulidya ${ }^{2}$, Waras Nurcholis ${ }^{2,3 *}$ \\ Afiliasi
${ }^{1}$ PT. Mahkotadewa Indonesia, Jl. Gaharu No.AA1, Jakarta Utara, DKI Jakarta, Indonesia
${ }^{2}$ Unit Kandang Hewan Percobaan, Pusat Studi Biofarmaka Tropika, Institut Pertanian Bogor, Bogor, Indonesia
${ }^{3}$ Departemen Biokimia, Fakultas Matematika dan Ilmu Pengetahuan Alam, Institut Pertanian Bogor, \\ Bogor, Indonesia
}

\section{Kata Kunci \\ $\rightarrow$ Antidiabetes \\ - Glukosa darah \\ $\rightarrow \mathrm{HbA} 1 \mathrm{C}$ \\ $\rightarrow$ JAMSI \\ Keyword \\ $\rightarrow$ Antidiabetic \\ Blood glucose \\ $\rightarrow \mathrm{HbA} 1 \mathrm{C}$ \\ $\Rightarrow$ JAMSI.}

Diterima 3 Januari 2019

Direvisi 30 Januari 2019 Disetujui 20 Maret 2019

* Penulis Koresponding Waras Nurcholis email: wnurcholis@apps.ipb.ac.id

\begin{abstract}
ABSTRAK
Penelitian ini bertujuan untuk membuktikan khasiat JAMSI, Jamu antidiabetes PT. Mahkotadewa Indonesia, secara preklinis pada tikus diabetes yang diinduksi dengan streptozotocin. Tikus jantan Sprague Dawley sebanyak 36 ekor dibagi secara acak menjadi 6 kelompok (masing-masing kelompok 6 tikus): kelompok normal, kelompok kontrol diabetes (diinduksi + air saline), kelompok kontrol positif (diinduksi + Glibenclamide $2.5 \mathrm{mg} / \mathrm{kg} \mathrm{BB}$ ), dan tiga kelompok perlakuan (diinduksi + JAMSI dengan dosis 0.27, 0.81, dan $1.62 \mathrm{ml} / \mathrm{kg} \mathrm{BB}$ ). Perlakuan diberikan selama 28 hari setelah diinduksi dengan streptozotocin. Pemberian JAMSI $1.62 \mathrm{ml} / \mathrm{kg}$ BB terbukti mempengaruhi penurunan kadar glukosa darah dan hemoglobin terglikosilasi (HbA1C) dibandingkan kelompok diabetes. Hasil ini mengindikasikan bahwa JAMSI berkhasiat sebagai antidiabetes.
\end{abstract}

\section{ABSTRACT}

This study was aimed to investigate the antidiabetic efficacy of JAMSI, an antidiabetic Jamu from PT. Mahkotadewa Indonesia, in streptozotocin induced diabetic rats. Thirty-six male rat Sprague Dawley were randomly divided into 6 groups (six rats in each group): normal group, diabetic control group (induced + oral saline), positive control group (induced + oral Glibenclamide $2.5 \mathrm{mg} / \mathrm{kg}$ body weight), and three treatment group (induced + oral JAMSI with $0.27,0.81$, and $1.62 \mathrm{ml} / \mathrm{kg}$ body weight). Treatments were administrated for 28 days after induced with streptozotocin. Ingestion of the JAMSI with dose of $1.62 \mathrm{ml} / \mathrm{kg}$ body weight affected blood glucose decrease and decreased glycosylated hemoglobin (HbA1C) levels compared to that in the diabetic control group. These results indicate that JAMSI possess antidiabetic propriety.

\section{PENDAHULUAN}

Diabetes melitus (DM) merupakan salah satu penyakit sindrom metabolit yang dicirikan oleh beberapa parameter diantaranya kelebihan karbohidrat (hyperglycemia), lipid (hyperlipedemia), protein (hyperaminoacidemia), dan rendahnya insulin (hypoinsulinaemia) (Zhang et al. 2014). Sampai saat ini, prevalensi kejadiaan DM dari beberapa kajian masih cukup tinggi. Pada tahun 2013 data dunia menunjukkan terdapat 382 juta orang mengalami diabetes, dan angka tersebut diprediksi akan semakin meningkat menjadi 592 juta pada 2035 (Guariguata et al. 2014). Berdasarkan Pusat Data dan Informasi, Kementrian Kesehatan (2014) menunjukkan bahwa pada tahun 2013 terdapat sekitar 12 juta orang di Indonesia yang mengalami DM. Penyakit DM dapat membahayakan untuk penderitanya karena dapat menyebabkan 
komplikasi diantaranya terjadinya gagal ginjal (Koye et al. 2019), dry eye syndromne (Burda et al. 2013), neuropati (Mora et al. 1998), hipertensi, jantung serta stroke (Takeda et al. 2014). Selain itu, penderita DM berpotensi mengalami kematian dua kali lebih tinggi dibandingkan yang bukan penderita DM. Untuk itu perlu diupayakan untuk menanggulangi penyakit DM, salah satunya dengan memanfaatkan tanaman obat yang cukup banyak di Indonesia.

PT. Mahkotadewa Indonesia telah mengembangkan jamu antidiabetes yang dinamai JAMSI yang merupakan ramuan dari beberapa tanaman obat antidiabetes Indonesia. Untuk itu, penelitian ini bertujuan untuk mengevaluasi khasiat sediaan jamu JAMSI sebagai antidiabetes pada hewan uji tikus yang diinduksi dengan streptozotocin berdasarkan parameter bobot badan, kadar glukosa darah, dan HbA1C.

\section{METODE}

Bahan

JAMSI jamu antidiabetes diperoleh dari PT. Mahkotadewa Indonesia. Sediaan JAMSI $100 \mathrm{ml}$ dibuat dengan komposisi air $(70 \mathrm{ml})$, madu $(20 \mathrm{ml})$, gula aren $(10 \mathrm{~g})$, ekstrak Phaleria macrocarpa $(120 \mathrm{mg})$, ekstrak Andrographis paniculata (120 mg), dan ekstrak Morinda citrifolia (64 mg). JAMSI dibuat menjadi 3 dosis, yaitu 0.27, 0.81, dan $1.62 \mathrm{ml} / \mathrm{kg}$ BB untuk digunakan dalam perlakuan terhadap hewan uji. Sementara itu, hewan uji yang digunakan adalah tikus Sprague Dawley jantan usia 12 minggu dengan berat sekitar 200-250 g yang diperoleh dari Pusat Pengujian Hewan dan Makanan Badan Pengawas Obat dan Makanan (BPOM). Hewan uji dikandangkan secara berkelompok 2-3 ekor per kandang dengan suhu ruang kandang $25^{\circ} \mathrm{C}$ dengan kelembapan $60-70 \%$. Pakan diberikan 15 gram per hari dan minum diberikan ad libitum.

\section{Uji In Vivo Antidiabetes Jamu JAMSI}

Induksi diabetes. Hewan dipuasakan selama 16 jam, diperiksa kadar glukosa dalam darah dengan menggunakan strip test Accu check untuk mengetahui kondisi basal hewan percobaan tersebut. Hewan coba diinduksi dengan streptozocin (STZ) (Sigma, St Louis, $\mathrm{MO}$ ) dengan dosis $40 \mathrm{mg} / \mathrm{kg}$ BB yang dilarutkan dalam buffer sitrat $0.05 \mathrm{M} \mathrm{pH} 4.5$ diinjeksikan intra peritoneal. Setelah 48 jam hewan dicek kadar gula dalam darahnya dengan Accu check ${ }^{\circledR}$ dan diambil serumnya untuk diperiksa kadar glukosa dalam darah serta persentase HbA1C.

Perlakuan. Hewan coba dibagi menjadi 6 kelompok masing-masing kelompok terdiri dari 6 ekor tikus. Kelompok perlakuan meliputi kelompok normal, kelompok kontrol diabetes (diinduksi STZ + air saline), kelompok kontrol positif (diinduksi STZ + Glibenclamide $2.5 \mathrm{mg} / \mathrm{kg} \mathrm{BB}$ ), dan tiga kelompok perlakuan (diinduksi STZ + JAMSI dengan dosis 0.27, 0.81, dan $1.62 \mathrm{ml} / \mathrm{kg}$ BB). Perlakuan diberikan per oral dengan sonde lambung selama 4 minggu. Kadar glukosa darah ditentukan dari sampel darah hewan yang telah dipuasakan 16 jam dengan menggunakan Accu Check ${ }^{\circledR}$ sebanyak 6 kali, yaitu sebelum induksi STZ, 48 jam setelah induksi STZ, hari ke 7, 14, 21 dan 28 setelah pencekokan. Selain itu, sebelum induksi perlakuan dan setelah perlakuan 28 hari dilakukan analisis kadar $\mathrm{HbA1C}$ dalam darah dengan menggunakan kit untuk tikus, yaitu Rat Hemoglobin A1c Assay Kit (Crystal Chem, USA) dengan metode analisis sesuai petunjuk pabrikan. Bobot badan tikus ditentukan tiap hari dan dirata-rata setiap satu minggu selama percobaan untuk melihat khasiat jamu yang diberikan dalam mempertahankan bobot badan hewan percobaan.

\section{Analisis Statistik}

Data disajikan dalam bentuk nilai rata-rata \pm SEM. ANOVA dilakukan untuk mengetahui adanya perbedaan antara perlakuan dengan menggunakan program SPSS 25.

\section{HASIL DAN PEMBAHASAN}

Penyakit DM salah satu indikatornya adalah adanya penurunan berat badan (Lau 2010). Induksi STZ menunjukkan keberhasilan untuk mencapai kondisi diabetes pada semua kelompok yang diinduksi dibandingkan dengan kelompok normal yang ditunjukkan dengan menurunnya bobot badan tikus (Gambar 1). Pada hari ke 14 sampai dengan hari 28 menunjukkan data bobot badan semua kelompok lebih rendah signifikan dibandingkan dengan kelompok normal $(p<0.05)$. Setelah 28 hari perlakuan dengan jamu JAMSI menunjukkan bahwa pada dosis 0.81 dan $1.62 \mathrm{mg} / \mathrm{kg}$ BB terjadi peningkatan bobot badan dibandingkan dengan kontrol diabetes dan kontrol positif glibenklamid $(2.5 \mathrm{mg} / \mathrm{kg} \mathrm{BB})$. Penggunaan JAMSI pada kedua dosis tersebut menunjukkan kenaikan bobot badan setelah 21 hari perlakuan. Dengan

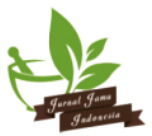


demikian, penggunaan jangka panjang dapat mencegah penurunan bobot badan hewan coba tikus.

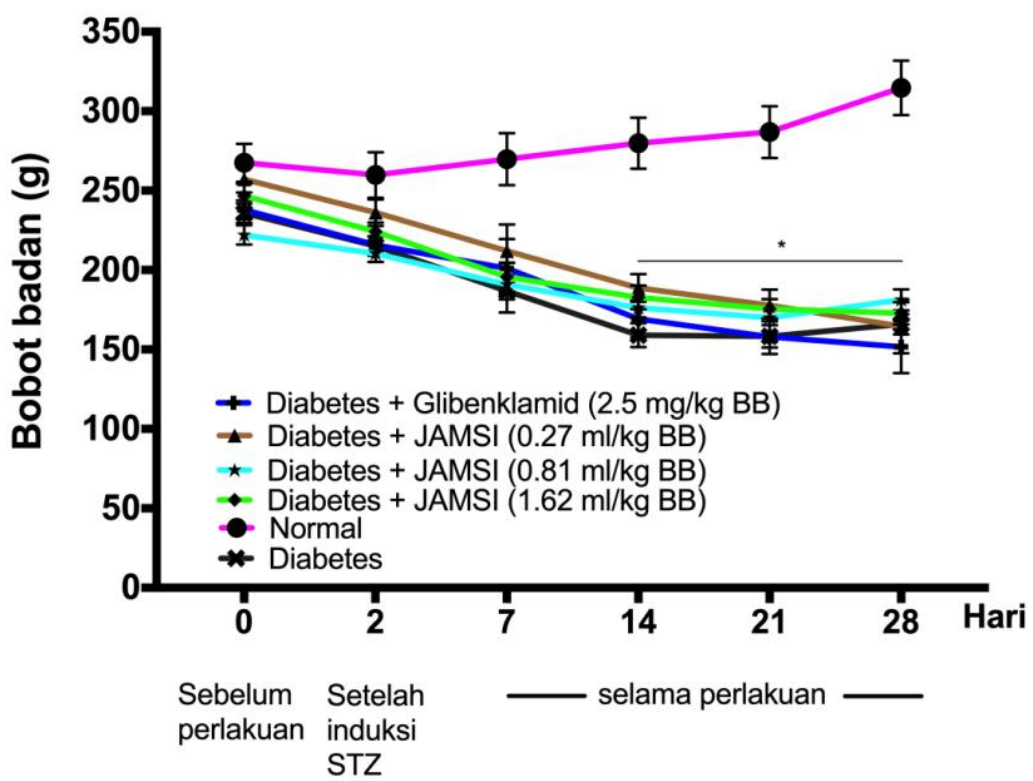

Gambar 1. Perubahan bobot badan tikus sebelum perlakuan, setelah induksi dengan streptozotocin (STZ) dan selama perlakuan pada 7, 14, 21, dan 28 hari. Nilai disajikan dalam rata-rata \pm SEM. *Berbeda signifikan dibandingkan kelompok Normal pada $\alpha=0.05$ berdasarkan uji Tukey.

Gambar 2 dan 3 secara berurutan menunjukkan kadar glukosa darah dan perubahannya sebelum dan setelah perlakuan dengan JAMSI. Kadar glukosa darah yang berlebih menjadi indikator awal terjadinya DM. Hal ini juga terlihat pada penelitian ini yaitu hewan dengan darah dibandingkan kelompok normal. Hal ini mengindikasikan bahwa induksi STZ pada dosis 40 $\mathrm{mg} / \mathrm{kg} \quad \mathrm{BB}$ berhasil membuat tikus perlakuan mengalami diabetes. Penggunaan JAMSI pada jangka panjang (28 hari) menunjukkan mampu menekan kenaikan glukosa darah dibandingkan dengan kelompok kontrol diabetes ataupun kontrol glibenklamid sebagai obat diabetes komersial. Selama 28 hari perlakuan, JAMSI pada dosis $1.62 \mathrm{ml} / \mathrm{kg}$ BB merupakan yang terbaik dalam menekan glukosa darah dan menyerupai dengan glibenklamid $(2.5 \mathrm{mg} / \mathrm{kg} \mathrm{BB})$ sebagai obat DM komersial (Gambar 3). Khasiat sebagai antidiabetes dari sediaan jamu JAMSI karena adanya kandungan ekstrak tanaman $P$. macrocarpa, $A$. paniculata, dan $M$. citrifolia. Dalam penelitian terpisah menunjukkan bahwa ketiga tanaman tersebut berkhasiat sebagai antidiabetes. Easmin et al. (2017) melaporkan bahwa tanaman P. macrocarpa berkhasiat sebagai antidiabetes melalui mekanisme penghambatan enzim $\alpha$-glukosidase. Penelitian lain dengan menggunakan tanaman $A$. paniculate yang dilakukan secara in vivo pada hewan coba tikus telah berhasil membuktikan khasiat antidiabetes melalui induksi STZ semuanya mengalami kenaikan glukosa mekanisme molekuler pensinyalan senyawa insulin (Augustine et al. 2014). M. citrifolia telah dilaporkan memiliki khasiat sebagai antioksidan yang tinggi dan berkhasiat sebagai antidiabetes (Ahmad et al. 2016). Dengan demikian, penggunaan ketiga tanaman dalam jamu JAMSI sangat baik dalam memberikan khasiat sebagai antidiabetes yang dibuktikan dalam penelitian ini.

Hemoglobin terglikosilasi (HbA1C) merupakan salah satu parameter lain terjadinya penyakit DM. Hal tersebut terjadi karena dalam kondisi glukosa darah tinggi (hiperglikemia) maka kelebihan glukosa akan bereaksi dengan protein sehingga menghasilkan hemoglobin terglikosilasi (HbA1C) (Jeffcoate 2004). Kadar $\mathrm{HbA1C}$ sebelum perlakuan dan setelah perlakuan tersaji pada Gambar 4. JAMSI terbukti dapat menurunkan kadar HbA1C dibandingkan dengan kontrol diabetes dengan khasiat penurunannya tidak berbeda nyata dengan standar glibenklamid pada dosis $2.5 \mathrm{mg} / \mathrm{kg}$ BB. Kadar HbA1C pada kelompok normal menunjukkan tidak berbeda nyata antara sebelum dan setelah perlakuan, sementara pada kelompok 
perlakuan menunjukkan perubahan yang besar. Hal tersebut mengindikasikan bahwa induksi STZ telah berhasil membentuk kondisi diabetes pada hewan coba tikus yang digunakan. Dengan demikian, penggunaan
JAMSI benar-benar terbukti berkhasiat sebagai antidiabetes baik berdasarkan kemampuan dalam menurunkan glukosa darah maupun menurunkan kadar HbA1C.

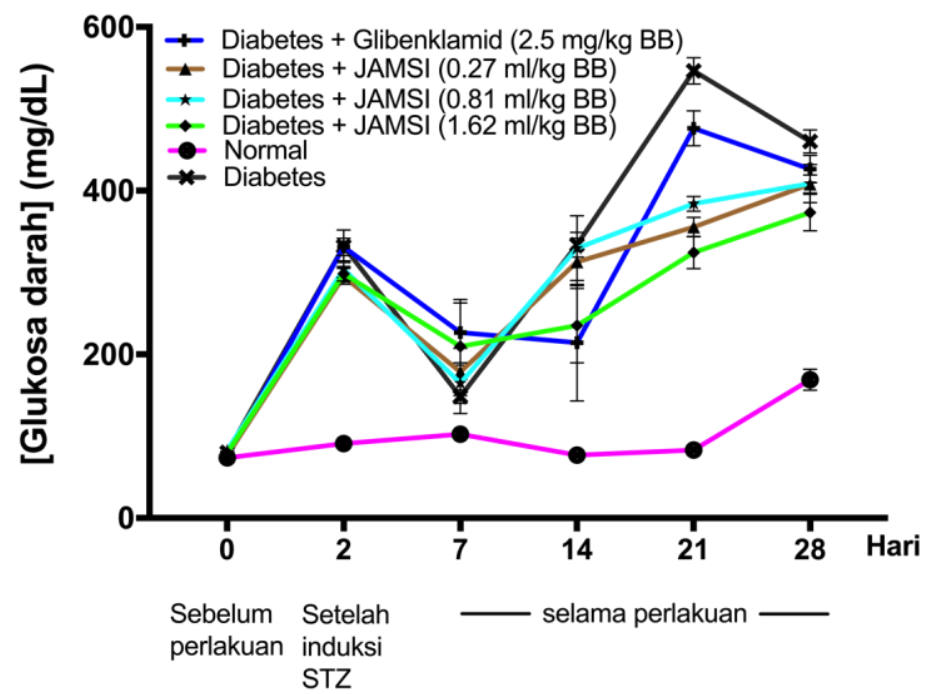

Gambar 2. Kadar glukosa darah pada tikus normal, diabetes, dan perlakuan setelah $0,2,7,14,21$, dan 28 hari pemberian JAMSI. Nilai disajikan dalam rata-rata \pm SEM.

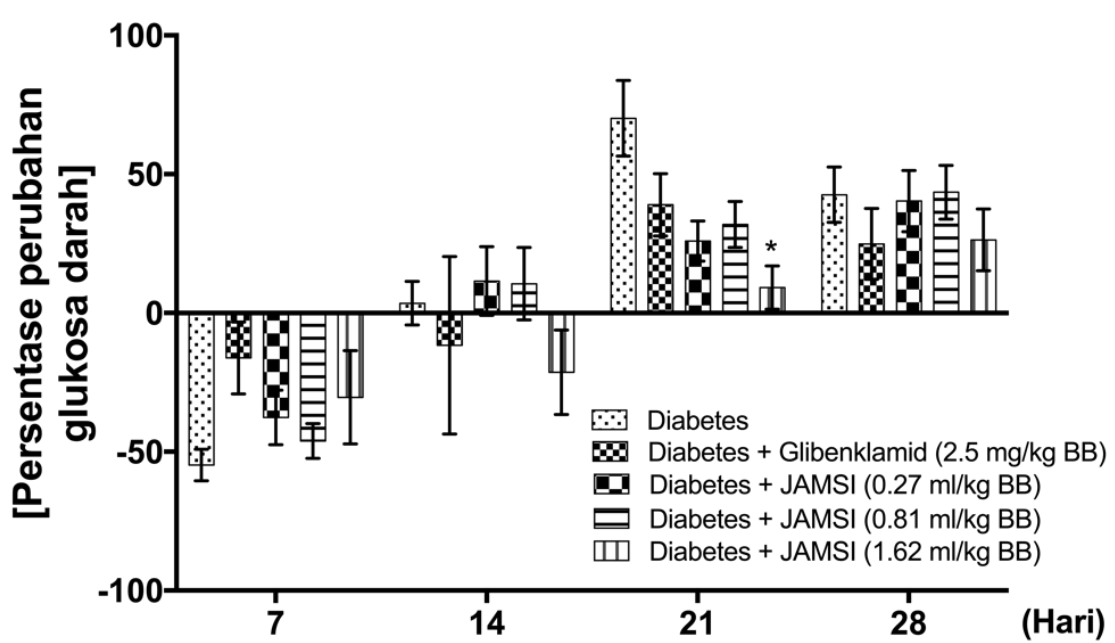

Gambar 3. Persentase perubahan kadar glukosa darah pada tikus normal, diabetes, dan perlakuan setelah 7, 14, 21, dan 28 hari pemberian JAMSI. Persentase perubahan didasarkan pada kadar glukosa darah setelah induksi STZ. Nilai disajikan dalam rata-rata \pm SEM. * Signifikan $(p<0.05)$ dibandingkan kelompok diabetes.

\section{SIMPULAN}

JAMSI dengan dosis $1.62 \mathrm{ml} / \mathrm{kg}$ BB terbukti secara preklinis sebagai antidiabetes pada hewan uji tikus yang diinduksi diabetes dengan streptozotocin. Evaluasi lebih lanjut perlu dilakukan khususnya untuk parameter biokimia lebih diperbanyak (seperti hormon insulin, lipid peroksida, dan perubahan metabolit melalui studi metabolomik) dan potensi penggunaannya dalam menanggulangi penyakit diabetes yang komplikasi dengan penyakit yang lain. 


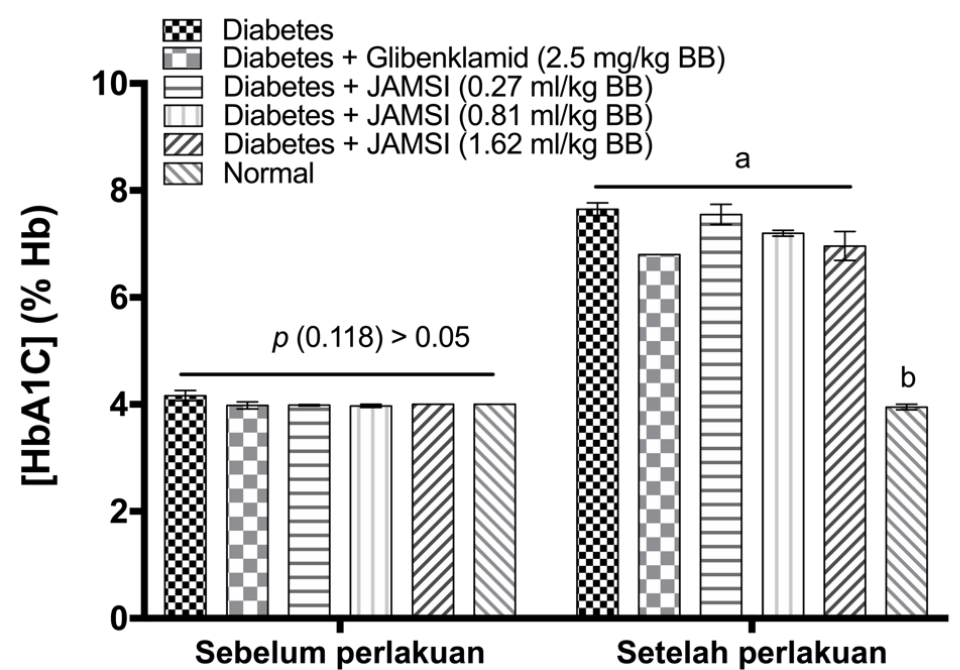

Gambar 4. Kadar HbA1C pada tikus normal, diabetes, dan perlakuan sebelum (hari ke-0) dan setelah (hari ke-28) perlakuan JAMSI. Nilai disajikan dalam rata-rata \pm SEM. Nilai yang diikuti oleh huruf yang berbeda pada waktu perlakuan yang sama menunjukkan berbeda signifikan pada $p<0.05$.

\section{DAFTAR PUSTAKA}

[Kemenkes] Kementrian Kesehatan. 2014. Situasi dan Analisis Diabetes. Jakarta (ID)

Ahmad AN, Mat Daud Z 'Azuan, Ismail A. 2016. Review on potential therapeutic effect of Morinda citrifolia L. Current Opinion in Food Science. 8:6267

Augustine AW, Narasimhan A, Vishwanathan $M$, Karundevi B. 2014. Evaluation of antidiabetic property of Andrographis paniculata powder in high fat and sucrose-induced type-2 diabetic adult male rat. Asian Pacific Journal of Tropical Disease. 4:S140-47

Burda N, Mema V, Mahmudi E, Selimi B, Zhugli S, et al. 2013. Prevalence of dry eye syndrome at patients with diabetus melitus TIP 2. Journal of Acute Disease. 2(1):48-51

Easmin S, Sarker MZI, Ghafoor K, Ferdosh S, Jaffri J, et al. 2017. Rapid investigation of $\alpha$-glucosidase inhibitory activity of Phaleria macrocarpa extracts using FTIR-ATR based fingerprinting. Journal of Food and Drug Analysis. 25(2):306-15

Guariguata L, Whiting DR, Hambleton I, Beagley J, Linnenkamp U, Shaw JE. 2014. Global estimates of diabetes prevalence for 2013 and projections for 2035. Diabetes Research and Clinical Practice. 103(2):137-49
Jeffcoate SL. 2004. Diabetes control and complications: the role of glycated haemoglobin, 25 years on. Diabetic Medicine. 21(7):657-65

Koye DN, Magliano DJ, Reid CM, Pavkov ME, Chadban SJ, et al. 2019. Trends in Incidence of ESKD in People With Type 1 and Type 2 Diabetes in Australia, 2002-2013. American Journal of Kidney Diseases. 73(3):300-308

Lau DCW. 2010. Diabetes and weight management. Primary Care Diabetes. 4:S24-30

Mora F, Lluch I, Ascaso J, Pascual I, Sempere J, et al. 1998. Esophageal motor disorders in diabetes mellitus patients with slight cardiovascular neuropaty. Gastroenterology. 114:A233

Takeda K, Nakamura K, Yagi T, Tatumi T, Moriguchi J, Ikeda M. 2014. The effect of sitagliptin on blood pressure in hypertension with diabetes melitus. Journal of the American Society of Hypertension. 8(4, Supplement):e110-11

Zhang X, Cui X, Li F, Wang S, Liu X, et al. 2014. Association between diabetes mellitus with metabolic syndrome and diabetic microangiopathy. Experimental and Therapeutic Medicine. 8(6):1867-73. 